\title{
Decrease in glycolytic flux in Saccharomyces cerevisiae cdc35-1 cells at restrictive temperature correlates with a decrease in glucose transport
}

\author{
L. J. W. M. Oehlen, † M. E. Scholte, W. de Koning $\ddagger$ and K. van Dam \\ Author for correspondence: K. van Dam. Tel: +3120 5255125. Fax: + 31205255124.
}

E. C. Slater Institute, BioCentrum, University of Amsterdam, Plantage Muidergracht 12, $1018 \mathrm{TV}$ Amsterdam, The Netherlands

\begin{abstract}
The glycolytic flux was investigated in the thermosensitive Saccharomyces cerevisiae adenylate cyclase mutant cdc35-1. Directly after a shift to restrictive temperature, the specific $\mathrm{CO}_{2}$ production rate increased from about $250 \mathrm{nmol} \mathrm{min}^{-1}$ (mg protein) ${ }^{-1}$ to more than $400 \mathrm{nmol} \mathrm{min}^{-1}\left(\right.$ mg protein) ${ }^{-1}$, but then the $\mathrm{CO}_{2}$ production gradually fell to about $70 \mathrm{nmol} \mathrm{min}^{-1}$ (mg protein) ${ }^{-1}$ after $5 \mathrm{~h} . \mathrm{O}_{2}$ consumption at restrictive temperature continued at more or less the same rate as at permissive temperature. The temperature shift in the mutant resulted in an increase in the estimated intracellular CAMP concentration from about $1.1 \mu \mathrm{M}$ to $1.8 \mu \mathrm{M}$. This indicates that high cAMP levels are not sufficient for cell cycle progression and high glycolytic activity. The decrease in glycolytic activity at restrictive temperature was not paralleled by a similar decrease in the specific activity of any of the glycolytic enzymes, but correlated with a decrease in hexose transport. A drop in intracellular concentrations of the early metabolites of glycolysis further indicated a defect in transport at restrictive temperature. Our data suggest that glucose transport has a high control on glycolytic flux.
\end{abstract}

Keywords: glycolytic flux, glucose transport, Saccharomyces cerevisiae, yeast, cell cycle mutant

\section{INTRODUCTION}

The RAS/adenylate cyclase pathway in Saccharomyces cerevisiae plays a pivotal role in the control of cell growth and cell division (reviewed by Thorner, 1982; Matsumoto et al., 1985; Tatchell, 1986; Broach, 1991). Components of the pathway which directly or indirectly regulate the adenylate cyclase activity include RAS, CDC25, IRA and CAP proteins (Toda et al., 1985; Camonis et al., 1986; Broek et al., 1987; Tanaka et al., 1989, 1990; Field et al., 1990a ; Fedor-Chaiken $e t$ al., 1990). The gene for adenylate cyclase, CYR1, was found to be allelic to the earlier described CDC35 gene (Casperson et al., 1985; Kataoka

\footnotetext{
†Present address: The Rockefeller University, Box 237, New York, NY 10021, USA.

$\ddagger$ Present address: Katholieke Universiteit Leuven, Lab. voor Cellulaire Biochemie, Instituut voor Plantkunde, Kardinaal Mercierlaan 92, B-3030 Heverlee, Belgium.

Abbreviations: RQ, respiratory quotient; 3-PGA, 3-phosphoglycerate;
} 2,3-PGA, 2,3-bisphosphoglycerate; 2doG, 2-deoxyglucose. et al., 1985; Boutelet et al., 1985). The original $c d c 35-1$ mutant was isolated as a thermosensitive cell division cycle mutant which, at restrictive temperature, arrested at the START point in the cell cycle (Hartwell, 1974; Reed, 1980). The mutant $c d c 35$, together with $c d c 25, c d c 19$ and $c d c 33$, belongs to a group of $c d c$ mutants which display class II START arrest. When class II START mutants are shifted to restrictive temperature, growth is inhibited and cells arrest as unbudded cells in the G1 phase (Reed, 1980). In contrast, class I START mutants (e.g. $c d c 28$ ) continue to grow and some can form characteristic projections called 'shmoos' when they arrest at START at restrictive temperature (Reed, 1980).

It has been shown previously that the growth defect in START II mutants is correlated with a marked decrease in glycolytic flux (Oehlen et al., 1993). In the present report, the mechanism of the decrease in glycolytic flux in $c d c 35-1$ was investigated in more detail. In $c d c 35-1$ cells the intracellular cAMP level rises after a shift to restrictive temperature. Since the glycolytic flux drops markedly in this mutant and cells arrest under restrictive conditions, 
this further indicates that cAMP levels per se are not a prime factor controlling glycolytic flux and that high levels of cAMP are not sufficient for cell cycle progression. The fall in glycolytic flux in $c d c 35-1$ cells correlates with a decrease in hexose transport. Our data suggest that hexose transport has a high control on glycolytic flux.

\section{METHODS}

Yeast strains and growth conditions. The haploid strains A364A (MATa ade1 ade 2 ura1 bis7 lys 2 tyr 1 gal1) and BR214-4a (MAT a cdc35-1 ade1 bis7 trp1 ura1 arg) of Saccharomyces cerevisiat were obtained from the Yeast Genetic Stock Center (Berkeley, CA, USA). The medium and growth conditions were as described previously (Oehlen et al., 1993).

Determination of glycolytic flux and $\mathrm{O}_{2}$ consumption. Gas production in the cultures was measured at the growth temperature in Warburg manometers using the direct method as described by Novak \& Mitchison (1986). Manometer flasks (volume $15 \mathrm{ml}$ ) were filled with $3 \mathrm{ml}$ culture and gas production was read every $15 \mathrm{~min}$. After each reading, the manometers were opened, adjusted to zero and closed again. While most of the $\mathrm{CO}_{2}$ produced by the cells is measured using this technique, $\mathrm{CO}_{2}$ produced in the mitochondria as a result of tricarboxylic acid cycle activity is not detected. When glucose is fully oxidized in the mitochondria, using $\mathrm{O}_{2}$ as the terminal electron acceptor, $\mathrm{CO}_{2}$ production and $\mathrm{O}_{2}$ consumption occur in equimolar amounts $\left(\mathrm{C}_{6} \mathrm{H}_{12} \mathrm{O}_{6}+6 \mathrm{O}_{2} \rightarrow 6 \mathrm{CO}_{2}+6 \mathrm{H}_{2} \mathrm{O}\right)$. Since the mitochondrially produced $\mathrm{CO}_{2}$ thus equals $\mathrm{O}_{2}$ consumption, specific total $\mathrm{CO}_{2}$ production rates were calculated by adding the $\mathrm{O}_{2}$ consumption rates to the gas production measured by direct Warburg techniques. The validity of this method has been shown by Lagunas (1979).

Respiratory activity was measured at the growth temperature in $1.4 \mathrm{ml}$ Oxygraph vessels supplied with a Clark electrode. Fresh samples from cultures grown at permissive and restrictive temperature were taken every $15 \mathrm{~min}$ and oxygen consumption was recorded continuously. The respiratory quotient (RQ) was calculated by dividing the specific $\mathrm{CO}_{2}$ production rates by the specific $\mathrm{O}_{2}$ consumption rates (Lagunas, 1979). Specific $\mathrm{CO}_{2}$ production and $\mathrm{O}_{2}$ consumption rates were expressed in $\mathrm{nmol} \mathrm{min}^{-1}$ (mg total cellular protein $)^{-1}$. The cellular protein content was calculated from the optical density of the cultures, based on previous determinations that an $\mathrm{OD}_{600}$ of 10 corresponds to $1 \mathrm{mg}$ total cellular protein $\mathrm{ml}^{-1}$. Alcohol concentrations were determined as described previously (Oehlen et al., 1993).

Preparation of cell-free extracts and enzyme assays. The preparation of cell extracts by glass bead disruption was as described by De Koning et al. (1991). Enzyme activities were determined spectrophotometrically at $340 \mathrm{~nm}$ and $30^{\circ} \mathrm{C}$. All enzyme assays were performed in $50 \mathrm{mM}$ Pipes buffer at $\mathrm{pH} 7.0$ following protocols described previously (Oehlen $e t$ al., 1993). Analyses were performed on a Cobas Bio automatic analyzer (Roche). Enzyme activities are expressed in $\mathrm{U}(\mathrm{mg} \text { protein })^{-1}$ in the extract, where one unit is equivalent to the conversion of one $\mu \mathrm{mol}$ substrate $\mathrm{min}^{-1}$. Protein was determined by means of the bicinchoninic acid reagent as described by the supplier (Sigma), using bovine serum albumin as a standard.

Determination of intermediates. For the determination of glycolytic intermediates, effectors of glycolysis and other metabolites, we used the extraction method described by De Koning \& Van Dam (1992). In brief, samples (containing about $5 \mathrm{mg}$ total cellular protein) were filtered on cellulose acetate filters (diameter $48 \mathrm{~mm}, 1.2 \mu \mathrm{m}$ pore-size, Schleicher and Schuell, Dassel, FRG) and quickly immersed in $3 \mathrm{ml}$ methanol kept at $-40^{\circ} \mathrm{C}$. The cells were resuspended and the filters removed. After addition of $5 \mathrm{ml}$ cold $\left(-40^{\circ} \mathrm{C}\right)$ chloroform, the cells were stored at $-80^{\circ} \mathrm{C}$ until extraction. Cells were extracted with $2 \cdot 2 \mathrm{ml}$ MOPS buffer $(4 \mathrm{mM}, \mathrm{pH} 7)$ at $-35^{\circ} \mathrm{C}$ by vigorous shaking for $1 \mathrm{~h}$. The extracts were concentrated by means of a Speedvac vacuum concentrator (Savant Instr. Inc., Hicksville, NY, USA) to a final volume of about $500 \mu \mathrm{l}$.

Unless stated otherwise, the concentrations of the various metabolites were determined spectrophotometrically in $50 \mathrm{mM}$ triethanolamine/ $\mathrm{HCl}$ (TEA) buffer at $\mathrm{pH} 7 \cdot 6$. Measurements were done at $37^{\circ} \mathrm{C}$ on a Cobas Bio automatic analyser, allowing handling of 24 samples simultaneously.

Determinations of glucose 6-phosphate, fructose 6-phosphate, fructose 1,6-bisphosphate, dihydroxyacetone phosphate, 3phosphoglycerate (3-PGA), 2-phosphoglycerate, phosphoenol pyruvate, pyruvate, citrate, ATP, NADH, NAD ${ }^{+}, \mathrm{ADP}$ and AMP were essentially as described by Bergmeyer (1974).

Fructose 2,6-bisphosphate concentrations were determined by means of the kinetic assay described by Van Schaftingen \& Hers (1983).

For the determination of 2,3-bisphosphoglycerate (2,3-PGA), a kinetic assay was used based on the ability of 2,3-PGA to stimulate 3-phosphoglycerate mutase. The assay mixture for this assay was composed as follows: $0.15 \mathrm{mM} \mathrm{NADH}$, $0.6 \mathrm{mM}$ ADP, $1 \mathrm{mM} \mathrm{MgSO}_{4}, 5 \mathrm{mM} \mathrm{KCl}, 2.5 \mathrm{mM}$ 3-PGA, $5.5 \mathrm{U}$ lactate dehydrogenase $\mathrm{ml}^{-1}, 0.8 \mathrm{U}$ enolase $\mathrm{ml}^{-1}, 2 \mathrm{U}$ pyruvate kinase $\mathrm{ml}^{-1}, 50 \mathrm{mM}$ TEA buffered at $\mathrm{pH} 7 \cdot 6$. The conversion of 3-PGA (and NADH) was started by addition of $0 \cdot 1 \mathrm{U}$ 3-phosphoglycerate mutase $\mathrm{ml}^{-1}$ and recorded at $340 \mathrm{~nm}$ on a Cobas Bio spectrophotometer. The degree of stimulation of this reaction by 2,3-PGA was measured and concentrations were calculated from a calibration curve in the range between 0 and $2 \mu \mathrm{M}$.

cAMP concentrations in the extracts were determined according to Tovey et al. (1974). This cAMP test is based on the competition of cAMP in the extract with $\left[{ }^{3} \mathrm{H}\right] \mathrm{cAMP}$ for the regulatory subunit of bovine cAMP-dependent protein kinase.

For protein determination $10 \mathrm{ml} 1 \mathrm{M} \mathrm{NaOH}$ was added to dried extracted cell material. To hydrolyse all proteins, this suspension was boiled for $15 \mathrm{~min}$ and subsequently cell debris were spun down. The protein content in the supernatant was determined by the Folin-Ciocalteu staining method, using bovine serum albumin as a standard. Cellular concentrations of the various metabolites were calculated as described previously (Oehlen et al., 1993).

Hexose uptake measurements. Uptake experiments of radiolabelled sugars were performed essentially as described by Bisson \& Fraenkel (1983a). Although we have recently reported an improvement on this method of hexose uptake (Walsh et al., 1994), the results obtained with this 'classical' method are comparable under the conditions of the present experiments. Cells from $c d c 35-1$ cultures were collected by filtration on cellulose acetate filters (diameter $48 \mathrm{~mm}, 1.2 \mu \mathrm{m}$ pore-size, Schleicher and Schuell) and washed with ice-cold potassium phosphate buffer $(100 \mathrm{mM}, \mathrm{pH} 6 \cdot 5)$. Cells were resuspended in phosphate buffer at $4{ }^{\circ} \mathrm{C}$ to a final concentration of $50 \mathrm{mg}$ wet weight $\mathrm{ml}^{-1}$ and kept on ice until they were used for uptake measurements.

For these measurements $50 \mu$ l of a suspension (preincubated aerobically at $30^{\circ} \mathrm{C}$ for $5 \mathrm{~min}$ ) was added to $12.5 \mu$ solution of radiolabelled sugar. After 5 to $40 \mathrm{~s}$ of incubation at $30^{\circ} \mathrm{C}$, 

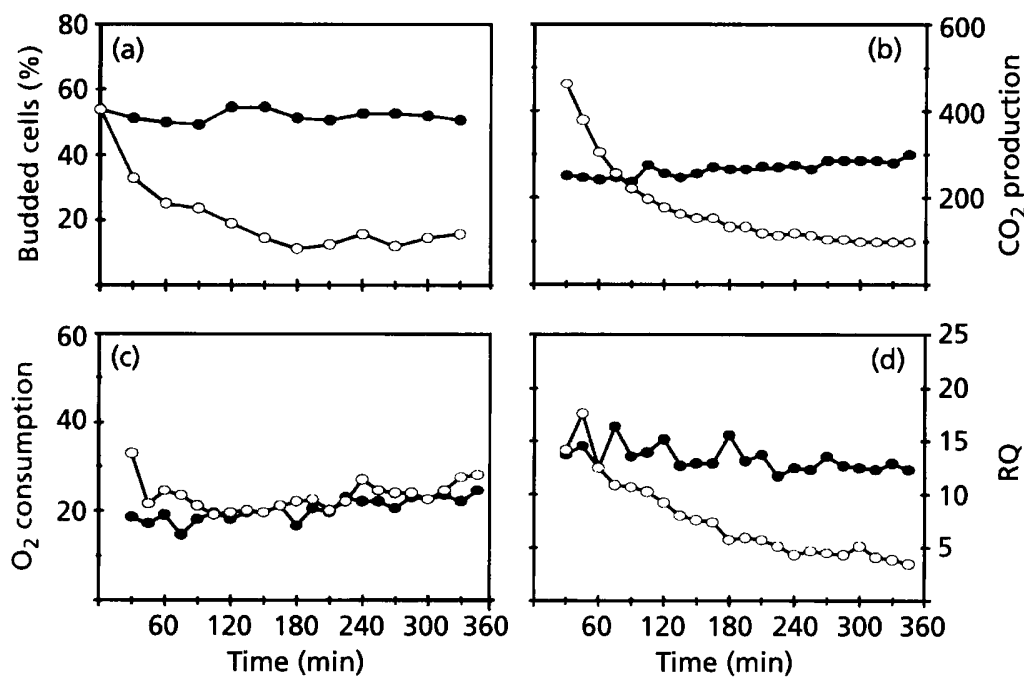

Fig. 1. $\mathrm{CO}_{2}$ production and $\mathrm{O}_{2}$ consumption in cdc35-1 cells after switching to restrictive temperature. cdc35-1 cells were grown to exponential phase and then a portion of the culture was kept at permissive temperature $\left(23^{\circ} \mathrm{C}, 0\right)$ and one portion switched to restrictive temperature $\left(36^{\circ} \mathrm{C}, O\right)$ at $t=0$. Data are representative for three independent experiments. (a) Percentage of budding cells was determined by microscopic scoring of at least 100 cells. (b) Specific $\mathrm{CO}_{2}$ production rates were determined by manometric techniques and are given in $\mathrm{nmol} \mathrm{min}^{-1}$ (mg protein) ${ }^{-1}$. (c) Specific $\mathrm{O}_{2}$ consumption rates in $\mathrm{nmol} \mathrm{min}^{-1}$ (mg protein) $)^{-1}$ were determined with a Clark electrode. (d) Respiratory quotient $=\mathrm{CO}_{2}$ production rate (data from panel b) divided by $\mathrm{O}_{2}$ consumption rate (data from panel c). uptake was terminated by adding $50 \mu \mathrm{l}$ of the mixture of cells and substrate to $10 \mathrm{ml}$ ice-cold phosphate buffer. The cells were immediately collected on glass-fibre filters (Whatman GF/F) and washed twice with $10 \mathrm{ml}$ ice-cold phosphate buffer to remove external radiolabel. Radioactivity on filters was quantified by liquid scintillation counting. The blank in each experiment had labelled substrate and cells added separately to the cold buffer. These samples were further processed as described above.

Uptake of 2-deoxy- $\left[{ }^{3} \mathrm{H}\right]$ glucose (2doG) was determined at concentrations of 2 and $50 \mathrm{mM}$. Specific activity of the label was $0.5 \mu \mathrm{Ci} \mu \mathrm{mol}^{-1}(1 \mathrm{Ci}=37 \mathrm{GBq})$. At $2 \mathrm{mM}$ of $2 \mathrm{doG}$, uptake was linear in time for at least $30 \mathrm{~s}$, whereas at $50 \mathrm{mM}$ uptake quickly levelled off after about $5 \mathrm{~s}$ (data not shown). In order to obtain optimal incorporation we therefore used incubations of $30 \mathrm{~s}$ at the low $2 \mathrm{doG}$ concentrations and $5 \mathrm{~s}$ at the high concentration. Measurements for glucose and 6-deoxyglucose transport were as described for 2-doG with a similar specific activity of the radiolabelled sugar.

Transport activities were expressed in $\mathrm{nmol} \mathrm{min}^{-1}$ (mg total cellular protein $)^{-\mathbf{1}}$. The cellular protein was determined by hydrolysing quantities of the concentrated cell suspensions in $1 \mathrm{M} \mathrm{NaOH}$. Samples were boiled for $15 \mathrm{~min}$ and subsequently cell debris were spun down. The protein content in the supernatant was determined according to Lowry's method, using bovine serum albumin as a standard.

\section{RESULTS}

\section{Glycolytic activity decreases in blocked cdc35-1 cells}

When exponential-phase BR214-4a cultures were transferred from permissive to restrictive temperature, cells stopped dividing and accumulated as unbudded cells (Fig. 1a). As expected, cells incubated at restrictive temperature for $6 \mathrm{~h}$ were arrested in G1 with unreplicated DNA (as determined by flow cytometry) and were approximately $40 \%$ bigger than cells under permissive conditions [cell size was determined as described previously (Van Doorn et al., 1988); data not shown].

Metabolic fluxes for $c d c 35-1$ mutant cells were followed by determining specific gas production rates $\left(\mathrm{CO}_{2}\right.$ production), specific $\mathrm{O}_{2}$ consumption rates and alcohol concentration in the cultures. Specific $\mathrm{CO}_{2}$ production

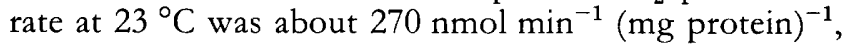
which is comparable to the $\mathrm{CO}_{2}$ production in wild-type cells under these conditions (Oehlen et al., 1993), and specific $\mathrm{O}_{2}$ consumption rates about $20 \mathrm{nmol} \mathrm{min}^{-1}$ ( $m g$ protein $^{-1}$ throughout the duration of the experiment (Fig. 1b, c). The respiratory quotient was $13 \cdot 5$, which agrees with data reported by, for example, Beck \& Von Meyenburg (1968) or Lagunas (1979) for wild-type cells grown in batch culture with excess glucose. When the cdc35-1 cells were switched to $36{ }^{\circ} \mathrm{C}$, the specific $\mathrm{CO}_{2}$ production rate immediately increased, an effect which had been found previously for wild-type cells (Oehlen et al., 1993). In contrast to wild-type cells, however, the $\mathrm{CO}_{2}$ production in $c d c 35-1$ cells gradually fell from more than $400 \mathrm{nmol} \mathrm{min}^{-1}$ ( $\mathrm{mg}$ protein) $)^{-1}$ just after the temperature-shift, to a level of about $70 \mathrm{nmol} \mathrm{min}{ }^{-1}(\mathrm{mg}$ protein) $)^{-1}$ after $6 \mathrm{~h}$ at restrictive temperature (Fig. 1b). As shown in Fig. 1c, specific $\mathrm{O}_{2}$ consumption rates in $c d c 35$ 1 cells were not affected in a similar way by the switch to restrictive temperature. With the exception of a short burst in $\mathrm{O}_{2}$ consumption just after the shift to restrictive conditions, both at $23{ }^{\circ} \mathrm{C}$ and at $36^{\circ} \mathrm{C}$ the specific $\mathrm{O}_{2}$ consumption rates were about $20 \mathrm{nmol} \mathrm{m^{-1 }}$ (mg protein $)^{-1}$. As a result of the change in $\mathrm{CO}_{2}$ production rates and the constant $\mathrm{O}_{2}$ consumption rates, the RQ fell from 13.5 to about 3.5 after $5 \mathrm{~h}$ at $36^{\circ} \mathrm{C}$ (Fig. 1d). As an alternative way of measuring glycolytic activity, ethanol concentrations were measured in cultures kept at permissive temperature and cultures switched to restrictive conditions. When cultures with a starting concentration of ethanol of about $6 \mathrm{mM}$ were kept at permissive temperature, the ethanol concentration increased exponentially, as expected, and reached a level of $19 \mathrm{mM}$ after $5.75 \mathrm{~h}$ of further incubation. When the same culture was shifted from $23{ }^{\circ} \mathrm{C}$ to the restrictive temperature of $36{ }^{\circ} \mathrm{C}$, ethanol concentrations initially increased faster than in the culture at permissive temperature, but then, after 


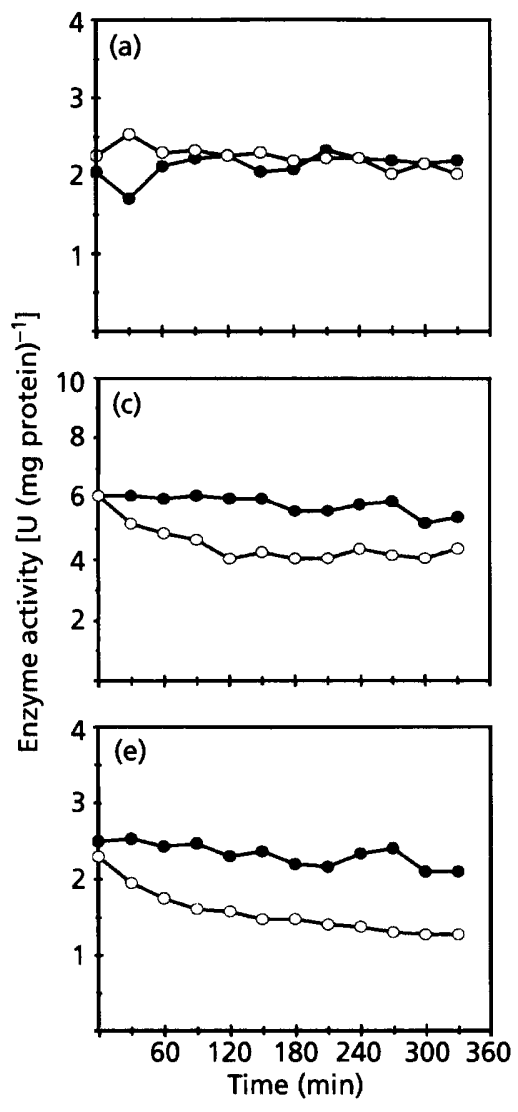

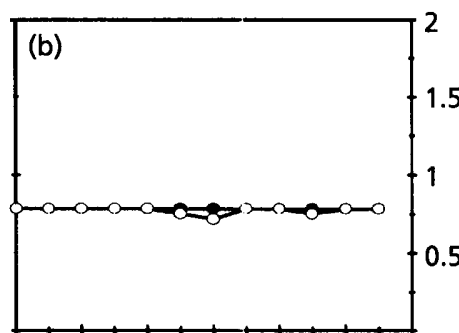
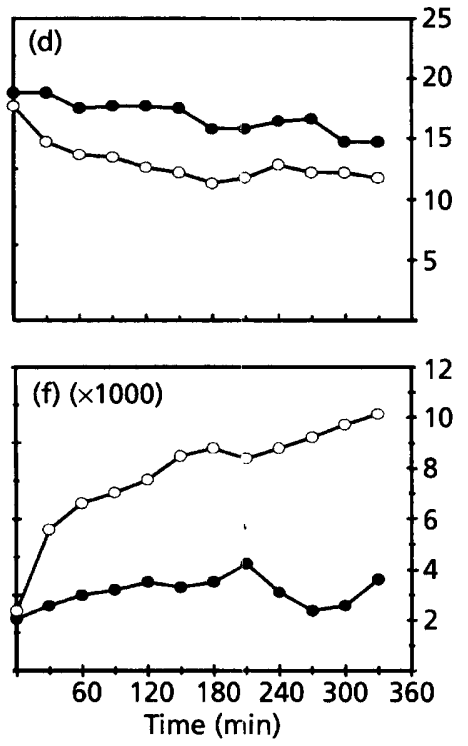

Fig. 2. Enzyme specific activities. The specific activities of selected glycolytic enzymes and fructose-1,6-bisphosphatase were determined for $S$. cerevisiae cdc35-1 cells kept at permissive temperature (0) or switched to restrictive temperature $(0)$ at $t=0$. Data points represent the mean of two experiments. (a) Hexokinase, (b) phosphofructo-1-kinase, (c) glyceraldehyde3-phosphate dehydrogenase, (d) pyruvate kinase, (e) pyruvate decarboxylase, (f) fructose-1,6-bisphosphatase. Note that fructose-1,6-bisphosphatase activities are multiplied by a factor of 1000 and are in the order of magnitude of $\mathrm{mU}(\mathrm{mg} \text { protein })^{-1}$. about $3 \mathrm{~h}$ at restrictive temperature, dropped below the concentrations measured for the culture at permissive temperature to reach a level of $10 \mathrm{mM}$ after $5.75 \mathrm{~h}$ at: restrictive temperature. This pattern of ethanol pro duction was in qualitative and quantitative agreement: with the observed changes in specific $\mathrm{CO}_{2}$ production rates.

\section{The decrease in glycolytic activity is not correlated with a similar change in the specific activity of glycolytic enzymes}

To assess whether the decrease in glycolytic flux was correlated with or caused by a decrease in the activity of one of the glycolytic enzymes, the specific activity of various enzymes of the glycolytic pathway was measured. The specific activity of most of these enzymes was unaffected by the change in growth temperature and the largest effects observed were decreases of 20 to $40 \%$ in the specific activity of glyceraldehyde-3-phosphate dehydrogenase, pyruvate kinase and pyruvate decarboxylase (Fig. 2). Virtually constant specific activities were measured at $23{ }^{\circ} \mathrm{C}$ and $36{ }^{\circ} \mathrm{C}$ for hexokinase and phosphofructokinase (Fig. 2) and glucose-6-phosphate isomerase [average activity about $4 \mathrm{U}$ (mg protein $)^{-1}$ ], aldolase [3-4 U (mg protein $\left.)^{-1}\right]$, 3-phosphoglycerate kinase $\left[10 \mathrm{U}(\mathrm{mg} \text { protein })^{-1}\right]$, phosphoglycerate mutase $\left[18 \mathrm{U}(\mathrm{mg} \text { protein })^{-1}\right]$, enolase $\left[4 \mathrm{U}(\mathrm{mg} \text { protein })^{-1}\right]$ and alcohol dehydrogenase $\left[6 \mathrm{U}(\mathrm{mg} \text { protein })^{-1}\right]$ (data not shown). As found previously for two $c d c 25$ mutants shifted to restrictive conditions (Oehlen et al., 1993), none of the glycolytic enzymes of $c d c 35-1$ mutants showed a decrease which correlated with the prominent decrease in in vivo glycolytic flux.

The specific activity of the gluconeogenic enzyme fructose-1,6-bisphosphatase increased from about $2 \mathrm{mU}$ $(\mathrm{mg} \text { protein })^{-1}$ at $23^{\circ} \mathrm{C}$ to about $10 \mathrm{mU}(\mathrm{mg} \text { protein })^{-1}$ after $5 \mathrm{~h}$ at restrictive temperature (Fig. 2). Throughout the duration of the experiment, however, the specific activity of FBPase remained several orders of magnitude lower than the activities of glycolytic enzymes.

\section{Levels of metabolites in blocked cdc35-1 cells}

In order to obtain further information about the molecular mechanisms underlying the observed decrease in glycolytic flux at restrictive temperature, the levels of several metabolites in $c d c 35-1$ cells at $23{ }^{\circ} \mathrm{C}$ and $36^{\circ} \mathrm{C}$ were determined. The estimated cellular concentrations of most intermediates of glycolysis decreased after shifting $c d c 35$ 1 cells from permissive to restrictive conditions (Table 1). Most prominent changes were observed for early intermediates of glycolysis, namely glucose 6-phosphate, fructose 6-phosphate, fructose 1,6-bisphosphate and for pyruvate. Changes in the concentrations of other metabolites were less pronounced and in some cases within the margin of experimental error. Concentrations 
Table 1. Estimated intracellular concentrations of various metabolites

S. cererisiae cdc $35-1$ cells were kept at a permissive temperature of $23^{\circ} \mathrm{C}$ or were switched to the restrictive temperature of $36^{\circ} \mathrm{C}$. Metabolite concentrations were determined spectrophotometrically in neutral extracts. Data are the mean and standard error for samples taken at 2, 3 and $4 \mathrm{~h}$ after the temperature shift. Energy charge was calculated as $([\mathrm{ATP}]+0 \cdot 5[\mathrm{ADP}]) /([\mathrm{ATP}]+[\mathrm{ADP}]+[\mathrm{AMP}])$.

\begin{tabular}{|lcc|}
\hline & $\begin{array}{c}\text { Intracellular metabolite concentration } \\
(\mathbf{m M} \text { except where stated) }\end{array}$ \\
\cline { 2 - 3 } & \multicolumn{1}{c}{$\begin{array}{c}\text { Permissive temperature } \\
\text { Restrictive temperature }\end{array}$} \\
\hline Glucose 6-phosphate & $2 \cdot 93 \pm 0 \cdot 08$ & $1 \cdot 45 \pm 0 \cdot 10$ \\
Fructose 6-phosphate & $0 \cdot 44 \pm 0 \cdot 03$ & $0 \cdot 24 \pm 0 \cdot 03$ \\
Fructose 1,6-bisphosphate & $3 \cdot 25 \pm 0 \cdot 09$ & $1 \cdot 17 \pm 0 \cdot 25$ \\
Dihydroxyacetone phosphate & $0 \cdot 55 \pm 0 \cdot 03$ & $0 \cdot 41 \pm 0 \cdot 06$ \\
3-Phosphoglycerate & $0 \cdot 82 \pm 0 \cdot 02$ & $0 \cdot 56 \pm 0 \cdot 07$ \\
2-Phosphoglycerate & $0 \cdot 08 \pm 0 \cdot 02$ & $0 \cdot 04 \pm 0 \cdot 02$ \\
Phosphoenol pyruvate & $0 \cdot 29 \pm 0 \cdot 10$ & $0 \cdot 27 \pm 0 \cdot 05$ \\
Pyruvate & $2 \cdot 97 \pm 0 \cdot 08$ & $1 \cdot 89 \pm 0 \cdot 13$ \\
NAD ${ }^{+}$ & $2 \cdot 92 \pm 0 \cdot 10$ & $3 \cdot 18 \pm 0 \cdot 19$ \\
ATP & $3 \cdot 14 \pm 0 \cdot 20$ & $2 \cdot 33 \pm 0 \cdot 20$ \\
ADP & $0 \cdot 50 \pm 0 \cdot 15$ & $0 \cdot 35 \pm 0 \cdot 15$ \\
AMP & $0 \cdot 20 \pm 0 \cdot 10$ & $0 \cdot 20 \pm 0 \cdot 10$ \\
Energy charge & $0 \cdot 88$ & $0 \cdot 87$ \\
cAMP & $1 \cdot 12 \pm 0 \cdot 06$ & $1 \cdot 78 \pm 0 \cdot 21 \mu \mathrm{M}$ \\
Fructose 2,6-bisphosphate & $10 \cdot 14 \pm 0 \cdot 73$ & $7 \cdot 21 \pm 0 \cdot 16 \mu \mathrm{M}$ \\
2,3-Bisphospho-glycerate & $243 \cdot 68 \pm 19 \cdot 86$ & $96 \cdot 55 \pm 3 \cdot 75 \mu \mathrm{M}$ \\
Citrate & $1 \cdot 84 \pm 0 \cdot 16$ & $8 \cdot 05 \pm 3 \cdot 29$ \\
\hline
\end{tabular}

of glyceraldehyde 3-phosphate were found to be too low to be reliably determined with the methods employed.

Although the concentrations of several intermediates of glycolysis were changed significantly by the temperature shift, and despite the observed decrease in in vivo glycolytic flux, cells were able to retain a high energetic status, as judged from the high energy charge in all samples taken at $23^{\circ} \mathrm{C}$ or $36^{\circ} \mathrm{C}$ (Table 1) (energy charge $=([\mathrm{ATP}]+0 \cdot 5[\mathrm{ADP}]) /([\mathrm{ATP}]+[\mathrm{ADP}]+[\mathrm{AMP}]))$. No major changes were found in $\mathrm{NAD}^{+}$levels (Table 1 ). NADH levels were too low to be reliably detected.

Because the $C D C 35$ gene encodes adenylate cyclase, and because cAMP and fructose-2,6-bisphosphate can regulate the activity of some glycolytic and gluconeogenic enzymes, cAMP and fructose-2,6-bisphosphate concentrations were determined. cAMP levels were found to rise after several hours at $36^{\circ} \mathrm{C}$, whereas fructose-2,6bisphosphate concentrations decreased (Table 1). Similar observations have been reported earlier for $c d c 25-1$ (Oehlen et al., 1993). Other potential effectors of glycolytic enzymes include 2,3-phosphoglycerate, which stimulates phosphoglycerate mutase activity, and citrate, which, in liver cells, can inhibit phosphofructokinase activity. Although the estimated cellular concentrations of 2,3-PGA decreased from more than $200 \mu \mathrm{M}$ to less than $100 \mu \mathrm{M}$, the level remained far above the concentration necessary for half-maximal stimulation of phosphoglycerate mutase of $0.5-0.8 \mu \mathrm{M}$ reported by
Sasaki et al. (1971). Citrate concentrations changed markedly in $c d c 35-1$ cells incubated at restrictive temperature: levels rose from less than $2 \mathrm{mM}$ to more than $20 \mathrm{mM}$ after $6 \mathrm{~h}$ at $36^{\circ} \mathrm{C}$ (Table 1 and data not shown). Preliminary results did not show any effect of citrate in this concentration range on the specific activity of phosphofructokinase in $S$. cerevisiae cell extracts (data not shown). Thus, although prominent changes in 2,3-PGA and citrate levels were observed in $c d c 35-1$ cells at restrictive temperature, these changes are not likely to have a major effect on phosphoglycerate mutase and phosphofructokinase activities, respectively.

\section{Hexose transport decreases in cdc35-1 cells under restrictive conditions}

The levels of some early intermediates of glycolysis were lower at $36{ }^{\circ} \mathrm{C}$ than at $23{ }^{\circ} \mathrm{C}$. Possible explanations for this phenomenon include (a) a decrease in hexokinase activity, and (b) a decrease in glucose transport. Since there was no indication for lowered hexokinase activity at restrictive temperature (Fig. 2), the second possibility was pursued. Hexose transport was measured in $c d c 35-1$ cells grown at $23{ }^{\circ} \mathrm{C}$ or incubated at $36{ }^{\circ} \mathrm{C}$ for different time intervals. The procedures of sampling, preparation of a concentrated cell suspension in buffer, and aerobic preincubation at $30^{\circ} \mathrm{C}$ did not affect ATP concentrations and the levels of various other metabolites including most intermediates of glycolysis (data not shown). Transport of 


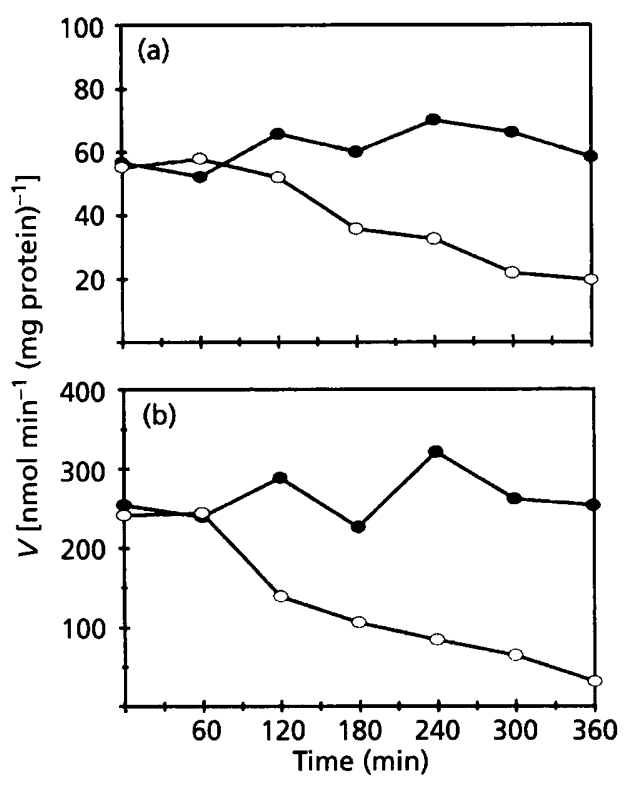

Fig. 3. Hexose transport in cdc35-1 cells. 2-doG uptake was; measured in $S$. cerevisiae cdc35-1 cultures kept at permissive temperature $(O)$ or shifted to $36^{\circ} \mathrm{C}(\mathrm{O})$ at $t=0$. Uptake was; determined in concentrated cell suspensions at 2-doGi concentrations of (a) $2 \mathrm{mM}$ or (b) $50 \mathrm{mM}$. Data are representative for two independent experiments.

the non-metabolizable glucose analogue 2-doG was measured at final sugar concentrations of 2 or $50 \mathrm{mM}$ at $30{ }^{\circ} \mathrm{C} .2$-doG is transported by the same carrier as glucose, it can be phosphorylated at the 6-hydroxyl position, but is not further metabolized. Schuddemat et al. (1986, 1988) have reported a $K_{\mathrm{m}}$ value for 2-doG transport of 0.5 (1986 paper) or $1.25 \mathrm{mM}$ (1988 paper) for wild-type cells. The cdc35-1 mutant was found to have a higher $K_{\mathrm{m}}$ for both glucose (4.3 mM; Walsh et al., 1994) and for 2-doG (approximately $5 \mathrm{mM}$; data not shown) at permissive: temperature. The transport measured at $50 \mathrm{mM}$ therefore: reflects $V_{\max }$ conditions for sugar transport. As shown in. Fig. 3 (a, b) sugar transport markedly decreased in $c d c 35-1$ cells incubated at $36^{\circ} \mathrm{C}$. This decrease was observed both at the low and the high sugar concentration tested. although the decrease in transport at $50 \mathrm{mM}$ appeared to be somewhat more pronounced than that at $2 \mathrm{mM}$. Similar observations were also made when radiolabelled glucose was used for the transport assays (data not shown). In a similar experiment with wild-type cells, glucose transport (measured at a final concentration of $100 \mathrm{mM}$ ) was approximately 1.5 times higher at $36^{\circ} \mathrm{C}$ than at $23{ }^{\circ} \mathrm{C}$ throughout the experiment (data not shown). Also when transport of the non-phosphorylatable glucose analogue 6-deoxyglucose was measured, a marked change in sugar transport in $c d c 35-1$ cells could be observed at $36^{\circ} \mathrm{C}$. Transport of this sugar (measured at a final concentration of $100 \mathrm{mM}$ ) decreased from approximately $400 \mathrm{nmol}$ $\mathrm{min}^{-1}$ (mg protein $)^{-1}$ at $23{ }^{\circ} \mathrm{C}$ to about $60 \mathrm{nmol} \mathrm{m^{-1 }}$ $(\mathrm{mg} \text { protein })^{-1}$ after $5 \mathrm{~h}$ at the restrictive temperature. All these transport data taken together indicate that the decrease in glycolytic activity in $c d c 35-1$ cells at restrictive temperature correlates with a defect in hexose transport activity.

\section{DISCUSSION}

\section{Adenylate cyclase may have CAMP-independent functions}

Since $c d c 35-1$ cells carry a thermosensitive mutation in the adenylate cyclase gene, cAMP levels might be expected to fall when $c d c 35-1$ carrying cells were shifted to restrictive temperature. Instead of a decrease, the intracellular cAMP levels were found to increase after a temperature shift, an effect that is usually observed for wild-type cells (Boutelet et al., 1985; Camonis et al., 1986; Oehlen et al., 1993). At restrictive temperature, the in vivo catalytic activity of adenylate cyclase from $c d c 35-1$ cells may therefore be similar to that of wild-type cells. Sy \& Tamai (1986) found that the in vitro adenylate cyclase activities of membranes prepared from $c d c 35-1$ cells grown at permissive temperature or incubated at restrictive temperature were the same. The enzyme, however, was altered in its dependency for $\mathrm{Mn}^{2+}$ and did not respond to guanine nucleotide stimulation. Based on these results it was suggested that the $c d c 35-1$ mutation was not in the catalytic site, but at a site where adenylate cyclase interacts with regulatory proteins. These in vitro properties of $c d c 35-1$ adenylate cyclase may help to explain the observed cAMP rise in vivo in $c d c 35-1$ at $36^{\circ} \mathrm{C}$.

In spite of the rise in cAMP levels $c d c 35-1$ cells arrest in the G1 phase of the cell cycle and the glycolytic flux of the cells at restrictive temperature gradually falls. Similar results have been reported earlier for $c d c 25-1$ carrying ts.321 cells (Oehlen et al., 1993) and they indicate that high cAMP levels may be necessary but not sufficient for cell cycle progression and the maintenance of a high glycolytic flux. Interestingly, it appears that adenylate cyclase, at least in mutant $c d c 35-1$ cells, can exert cAMP-independent effects which lead to G1 arrest and a lowering of glycolytic flux. It remains to be established what the nature of these cAMP-independent pathways is and whether they are of importance for normal physiological regulation in cells with wild-type adenylate cyclase. It may be relevant to note that adenylate cyclase has been reported to be associated with at least two proteins (CAP and RAS), which, apart from their role in the regulation of adenylate cyclase activity, appear to be involved in cAMP-independent pathways (Field et al., 1990b; Wigler et al., 1988; Field et al., 1990a ; Fedor-Chaiken et al., 1990; Gerst et al., 1991; Vojtek et al., 1991; Wang et al., 1992). It is unclear, however, whether these CAP-and RAS-mediated cAMP-independent pathways can contribute to cell cycle arrest and a lowered glycolytic activity.

\section{Hexose transport activity}

When $c d c 35-1$ cells were incubated at restrictive temperature for $5 \mathrm{~h}$ hexose transport activity decreased significantly. Schuddemat et al. $(1986,1988)$ have reported monophasic transport kinetics for 2-doG transport with a 
$K_{\mathrm{m}}$ of 0.5 or $1.25 \mathrm{mM}$ for wild-type cells and we found for the $c d c 35-1$ mutant a higher $K_{\mathrm{m}}$ of about $5 \mathrm{mM}$ for 2-doG transport. Our measurements at $50 \mathrm{mM}$ are likely to closely reflect the $V_{\max }$ for hexose transport. Although the number of glucose transporter molecules was not directly quantified, the decrease in overall $V_{\max }$ indicates that the total number of glucose transporters gradually falls in $c d c 35-1$ cells at restrictive temperature. A possible explanation for this decrease may lie in the fact that protein synthesis in $c d c 35-1$ mutant cells is much diminished. The half-life for glucose transporter molecules is relatively short compared to the half-lives of other proteins (Lagunas et al., 1982; López \& Gancedo, 1979). Inhibition of protein synthesis therefore could result in a decrease in the steady-state amount of glucose transporter molecules ( $\mathrm{mg}$ total cellular protein) ${ }^{-1}$ (Lagunas et al., 1982). Iida \& Yahara (1984) showed that the total protein synthesis rate in $c d c 35-1$ cells drops significantly when cells are incubated at restrictive temperature. This decrease in overall protein synthesis rate may contribute to a decrease in the number of glucose transporter molecules per mg protein, but it is unclear if the kinetics of the decrease in protein synthesis activity can fully explain the kinetics of the decrease in hexose transport activity. It is possible that additional, more specific mechanisms for the decrease in glucose transport exist.

\section{Regulation of glycolytic flux}

The gradual fall in glycolytic flux in S. cerevisiae cdc35-1 cells at restrictive temperature is not parallelled by a similar fall in the specific activity of any of the glycolytic enzymes, but is correlated with a decrease in hexose transport. Thus, at least in this experimental setting, glucose transport is likely to be an important factor in controlling glycolytic flux. A flux-controlling role for glucose transport was earlier suggested from experiments of Lagunas et al. (1982), who observed a correlation between a decrease in flux and a decrease in glucose transport when cells were starved for nitrogen. In addition to the correlation between flux and transport measurements in arrested $c d c 35-1$ cells, other data indicate the importance of transport in controlling glycolytic flux. The specific activities of glycolytic enzymes and the distribution of glycolytic intermediates in $c d c 35-1$ cells at restrictive temperature do not point to any other step in glycolysis which might be inhibited. There were, for example, no indications for restrictions of phosphofructokinase or phosphoglycerate mutase activities, which might result from an increase in citrate levels and a decrease in 2,3-PGA levels respectively. Also the changes in cAMP and fructose 2,6-bisphosphate levels did not seem to affect PFK or other enzymes of glycolysis. The observation that the $V_{\max }$ for hexose transport was similar to that of the in vivo glycolytic flux could be regarded as another argument in favour of a prominent role for hexose transport in controlling glycolytic flux. It should be noted, however, that our observation that the decrease in flux during the first hour at restrictive temperature is not parallelled by a decrease in transport, suggests that, at least during the first hour, other factors may be involved in the control of glycolytic flux.

Under permissive conditions, most of the glucose that enters the cell is converted to ethanol $/ \mathrm{CO}_{2}$ and only $2-3 \%$ is oxidized in the mitochondria to $\mathrm{CO}_{2}$ and water. The decrease in fermentative ethanol $/ \mathrm{CO}_{2}$ production in cdc35-1 cells at restrictive temperature is not parallelled by a decrease in $\mathrm{O}_{2}$ consumption. This distribution between respiration and fermentative ethanol $/ \mathrm{CO}_{2}$ production, indicated by the respiratory quotient, resembles - as in many other aspects - the fall in RQ when yeast cells are starved for their nitrogen source (Lagunas et al., 1982). Käppeli (1986) has proposed that ethanol production in $S$. cerevisiae is the result of an overflow metabolism at the level of pyruvate. According to this hypothesis, reduction of the input into the glycolytic pathway and reduced levels of pyruvate would in the first place affect fermentative ethanol $/ \mathrm{CO}_{2}$ production. The fall in $\mathrm{RQ}$, both in $c d c 35-1$ cells at restrictive temperature and in nitrogen starved cells, is consistent with this 'overflow' hypothesis.

\section{ACKNOWLEDGEMENTS}

We are indebted to the Department of Molecular Cell Biology, University of Amsterdam, for allowing us to use the Coulter counter and flow cytometric facilities and to Dr P. J. A. van den Broek for providing reagents. We also want to thank Drs J. M. Thevelein and P. W. Postma for stimulating discussions and comments on the manuscript. W.d.K. was supported by Gistbrocades BV, Delft, The Netherlands.

\section{REFERENCES}

Beck, C. \& Von Meyenburg, K. (1968). Enzyme patterns and aerobic growth of Saccharomyces cerevisiae under various degrees of glucose limitation. J Bacteriol 96, 479-486.

Bergmeyer, H. U. (1974). Methods of Enzymatic Analysis, 2nd edn. Academic Press: New York.

Bernt, E. \& Gutmann, I. (1974). Ethanol. Determination with alcohol dehydrogenase and NAD. In: Methods in Enzymatic Analysis, pp. 1499-1502. Edited by H. U. Bergmeyer. New York: Academic Press.

Bisson, L. F. \& Fraenkel, D. G. (1983a). Involvement of kinases in glucose and fructose uptake by Saccharomyces cerevisiae. Proc Natl Acad Sci US A 80, 1730-1734.

Bisson, L. F. \& Fraenkel, D. G. (1983b). Transport of 6deoxyglucose in Saccharomyces cerevisiae. J Bacteriol 155, 995-1000.

Boutelet, F., Petitjean, A. \& Hilger, F. (1985). Yeast $c d c 35$ mutants are defective in adenylate cyclase and are allelic with $c y r 1$ mutants while $C A S 1$, a new gene, is involved in the regulation of adenylate cyclase. EMBO J 4, 2635-2641.

Broach, J. R. (1991). RAS genes in Saccharomyces cerevisiae -- signal transduction in search of a pathway. Trends Genet 7, 28-33.

Broek, D., Toda, T., Michaeli, T., Levin, L., Birchmeier, C., Zoller, M., Powers, S. \& Wigler, M. (1987). The S. cerevisiae CDC25 gene product regulates the RAS/Adenylate cyclase pathway. Cell 48, 789-799.

Busturia, A. \& Lagunas, R. (1986). Catabolite inactivation of the glucose transport systems in Saccharomyces cerevisiae. J Gen Microbiol 132, 379-385.

Camonis, J. H., Kalekine, M., Gondre, B., Garreau, H., BoyMarcotte, E. \& Jacquet, M. (1986). Characterization, cloning and 
sequence analysis of the $C D C 25$ gene which controls the cyclic AMP level of Saccharomyces cerevisiae. EMBO J 5, 375-380.

Casperson, G. F., Walker, N. \& Bourne, H. R. (1985). Isolation of the gene encoding adenylate cyclase in Saccharomyces cerevisiae. Proc Natl Acad Sci US A 82, 5060-5063.

De Koning, W. \& Van Dam, K. (1992). A method for the determination of changes of glycolytic metabolites in yeast on a subsecond time scale using extraction at neutral $\mathrm{pH}$. Anal Biochem 204, 118-123.

De Koning, W., Groeneveld, K., Oehlen, L. J. W. M., Berden, J. A. \& Van Dam, K. (1991). Changes in the activities of key enzymes of glycolysis during the cell cycle in yeast - a rectification. $J$ Gen Microbiol 137, 971-976.

Fedor-Chaiken, M., Deschenes, R. J. \& Broach, J. R. (1990). SR V2, a gene required for RAS activation of adenylate cyclase in yeast. Cell 61, 329-340.

Field, J., Vojtec, A., Ballester, R., Bolger, G., Colicelli, J., Ferguson, K., Gerst, J., Kataoka, T., Michaeli, T., Powers, S., Riggs, M., Rodgers, L., Wheland, B. \& Wigler, M. (1990a). Cloning and characterization of CAP, the $S$. cerevisiae gene encoding the $70 \mathrm{kd}$ adenylyl cyclase-associated protein. Cell 61, 319-327.

Field, J., Xu, H. P., Michaeli, T., Ballester, R., Sass, P., Wigler, M. \& Colicelli, J. (1990b). Mutations of the adenylyl cyclase gene that block RAS function in Saccharomyces cerevisiae. Science 247, 464-467.

Gerst, J. E., Ferguson, K., Vojtek, A., Wigler, M. \& Field, J. (1991). CAP is a bifunctional component of the Saccharomyces cerevisiae adenylyl cyclase complex. Mol Cell Biol 11, 1248-1257.

Hartwell, L. H. (1974). Saccharomyces cerevisiae cell cycle. Bacteriol Rev 38, 164

lida, H. \& Yahara, I. (1984). Specific early-G1 blocks accompanied with stringent response in Saccharomyces cerevisiae lead to growth arrest in resting state similar to the GO of higher eucaryotes. J Cell Biol 98, 1185-1193.

Kataoka, T., Broek, D. \& Wigler, M. (1985). DNA sequence and characterization of the $S$. cerevisiae gene encoding adenylate cyclase. Cell 43, 493-505.

Käppeli, O. (1986). Regulation of carbohydrate metabolism in Saccharomyces cerevisiae and related yeasts. Adv Microb Physiol 28, 181-209.

Lagunas, R. (1979). Energetic irrelevance of aerobiosis for Saccharomyces cerevisiae growing on sugars. Mol Cell Biochem 27, 139-146.

Lagunas, R., Dominguez, C., Busturia, A. \& Sacz, M. J. (1982). Mechanisms of appearance of the Pasteur effect in Saccharomyces cerevisiae: inactivation of sugar transport system. $J$ Bacteriol 152, 19-25.

López, S. \& Gancedo, J. M. (1979). Effect of metabolic conditions on protein turnover in yeast. Biocbem J 178, 769-776.

Matsumoto, K., Uno, I. \& Ishikawa, T. (1985). Genetic analysis of the role of cAMP in yeast. Yeast 1, 15-24.

Novak, B. \& Mitchison, J. M. (1986). Change in the rate of $\mathrm{CO}_{2}$ production in synchronous cultures of the fission yeast Schizosaccharomyces pombe: a periodic cell cycle event that persists after the DNA-division cycle has been blocked. J Cell $S_{c i} \mathbf{8 6}$, 191-206.

Oehlen, L. J. W. M., Scholte, M. E., De Koning, W. \& Van Dam, K. (1993). Inactivation of the CDC25 gene product in Saccharomyces cerevisiae leads to a decrease in glycolytic activity which is independent from cAMP levels. J Gen Microbiol 139, 2091-2100.
Reed, S. I. (1980). The selection of Saccharomyces cerevisiae mutants defective in the start event of cell division. Genetics 95, 561-577.

Sasaki, R., Hirose, M., Sugimoto, E. \& Chiba, H. (1971). Studies on a role of the 2,3-diphosphoglycerate phosphatase activity in the yeast phosphoglycerate mutase reaction. Biochim Biophys Acta 227, 595-607.

Schuddemat, J., van den Broek, P. J.A. \& van Steveninck, J. (1986). Effect of xylose incubation on the glucose transport system in Saccharomyces cerevisiae. Biocbim Biophys Acta 861, 489-493.

Schuddemat, J., van den Broek, P. J. A. \& van Steveninck, J. (1988). The influence of ATP on sugar uptake mediated by the constitutive glucose carrier of Saccharomyces cerevisiae. Biochim Biophys Acta 937, 81-87.

Sy, J. \& Tamai, Y. (1986). An altered adenylate cyclase in $c d c 35-1$ cell division cycle mutant of yeast. Biochem Biophys Res Commun 140, 723-727.

Tanaka, K., Matsumoto, K. \& Toh-e, A. (1989). IRA1, an inhibitory regulator of the RAS-cyclic AMP pathway in Saccharomyces cerevisiae. Mol Cell Biol 9, 757-768.

Tanaka, K., Nakafuku, M., Tamanoi, F., Kaziro, Y., Matsumoto, K. \& Toh-e, A. (1990). IR A2, a second gene of Saccharomyces cerevisiae that encodes a protein with a domain homologous to mammalian ras GTPase-activating protein. Mol Cell Biol 10, 4303-4313.

Tatchell, K. (1986). RAS genes and growth control in Saccharomyces cerevisiae. J Bacteriol 166, 364-367.

Thorner, J. (1982). An essential role for cAMP in growth control: the case for yeast. Cell 30, 5-6-2133.

Toda, T., Uno, I., Ishikawa, T., Powers, S., Kataoka, T., Broek, D., Cameron, S., Broach, J., Matsumoto, K. \& Wigler, M. (1985). In yeast, RAS proteins are controlling elements of adenylate cyclase. Cell 40, 27-36.

Tovey, K. C., Oldham, K. G. \& Whelan, J. A. M. (1974). A simple direct assay for cyclic AMP in plasma and other biological samples using an improved competitive binding technique. Clin Cbim Acta 56, 221-234.

Van Doorn, J., Valkenburg, J. A. C., Scholte, M. E., Oehlen, L. J. W. M., van Driel, R., Postma, P. W., Nanninga, N. \& van Dam, K. (1988). Changes in activities of several enzymes involved in carbohydrate metabolism during the cell cycle. $J$ Bacteriol 170 , 4808-4815.

Van Schaftingen, E. \& Hers, H. G. (1983). Fructose 2,6bisphosphate in relation with the resumption of metabolic activity in slices of Jerusalem artichoke tubers. FEBS Lett 164, 195-200.

Vojtek, A., Haarer, B., Field, J., Gerst, J. T., Pollard, D., Brown, S. \& Wigler, M. (1991). Evidence for a functional link between profilin and CAP in the yeast $S$. cerevisiae. Cell 66, 497-505.

Walsh, M. C., Smits, H. P., Scholte, M. \& Van Dam, K. (1994). Affinity of glucose transport in Saccharomyces cerevisiae is modulated during growth on glucose. J Bacteriol 176, 953-958.

Wang, J., Suzuki, N. \& Kataoka, T. (1992). The 70-kilodalton adenylyl cyclase-associated protein is not essential for interaction of Saccharomyces cerevisiae adenylyl cyclase with RAS proteins. Mol Cell Biol 12, 4937-4945.

Wigler, M., Powers, S., Broek, D., Toda, T., Cameron, S., Nikawa, J., Michaeli, T., Colicelli, J. \& Ferguson, K. (1988). Studies of RAS function in the yeast Saccharomyces cerevisiae. Cold Spring Harbor Symp Quant Biol LIII, 649-655.

Received 13 January 1994; revised 9 March 1994; accepted 14 March 1994. 